\title{
Frying Time and Temperature Conditions' Influences on Physicochemical, Texture, and Sensorial Quality Parameters of Barley-Soybean Chips
}

\author{
Huda Abdalrahman AL Jumayi $\mathbb{D i D}^{1}$ and Amira M. G. Darwish $\mathbb{D}^{2}$ \\ ${ }^{1}$ Nutrition and Food Science Department, Faculty of Science, Taif University, Taif, Saudi Arabia \\ ${ }^{2}$ Food Technology Department, Arid Lands Cultivation Research Institute (ALCRI), \\ City of Scientific Research and Technological Applications (SRTACity), Alexandria 21934, Egypt
}

Correspondence should be addressed to Amira M. G. Darwish; amiragdarwish@yahoo.com

Received 29 July 2021; Revised 18 September 2021; Accepted 23 September 2021; Published 5 October 2021

Academic Editor: Iqra Shahzadi

Copyright (c) 2021 Huda Abdalrahman AL Jumayi and Amira M. G. Darwish. This is an open access article distributed under the Creative Commons Attribution License, which permits unrestricted use, distribution, and reproduction in any medium, provided the original work is properly cited.

\begin{abstract}
Demand for innovative healthy snacks that achieve consumer satisfaction represents increased interest for competitive food producers. The aim of this work was the assessment of physicochemical and sensory quality of barley-soybean chips involving legume protein flours by studying the effects of different substitution levels (10,20, and 30\%) of defatted soybean (DSB) flour, frying temperatures $\left(150,170\right.$, and $\left.190^{\circ} \mathrm{C}\right)$, and frying times $(60,90$, and $120 \mathrm{sec})$. The chips' moisture content was significantly decreased with increased frying temperature and time. The moisture content $(1.40 \%)$ was achieved at $10 \%$ DSB fried at $190^{\circ} \mathrm{C}$ for $120 \mathrm{sec}$. The least absorbed oil (29.25\%) was achieved at the least substitution percentage (10\% DSB), the least frying temperature $\left(150^{\circ} \mathrm{C}\right)$, and the least frying time $(60 \mathrm{sec})$. These results were reflected on sensorial parameters that revealed that the most preferred chips were barley-soybean chips with $10 \%$ DSB fried at 150 and $170^{\circ} \mathrm{C}$. The amylose content was increased by $33.80 \%$ in chips substituted with $30 \%$ DSB, while it was decreased to $27.16 \%$ in chips substituted with $10 \%$ DSB, and vice versa for the amylopectin content. TPA revealed that DSB substitution levels were directly proportional with hardness and inversely proportional with elasticity and adhesiveness. From obtained results, substitution levels with $10 \%$ DSB fried at $150^{\circ} \mathrm{C}$ are recommended. These findings encourage the production of innovative enhanced snacks involving legume protein while maintaining consumer satisfaction.
\end{abstract}

\section{Introduction}

Snacking is the intake of foodstuff between main meals and/ or consuming "snack foods" typically identified as energydense and nutrient-poor [1]. Healthy snacking became recommended for weight gain control, increased mental ability, and boosting energy. Awareness about the benefits of healthy snacks can be effective strategies for promoting healthy snack consumption and helping consumers adhere to healthful diets. Blending cereals and legumes enhance diets by increasing protein and carbohydrate contents. Regular intake of these biofunctional flours is an attractive option for people who are looking for healthier options [2-4].
Barley (Hordeum vulgare) took an important role in human nutrition and health due to its nutritional characteristics and adaptability to different environmental growing conditions [5, 6]. Barley contains high carbohydrate, moderate protein, and significant content of phosphorus and potassium [7]. Additionally, barley seeds contain rich amounts of dietary fiber, especially $\beta$-glucan, which has useful health influences, e.g., lowering cholesterol, reducing the inflammatory response, and boosting the immune system [8]. Soybean (Glycine max) is a protein-rich oilseed widely employed in the food industry. The global soy food market is expected to reach the value of 53.1 billion US\$ by 2024 [9]. Soybean is supplied as a source of high-quality protein, low saturated fat content, and high in vitamins C 
and B and a good source of calcium and potassium and provides many health benefits (lowering of the blood cholesterol level, increasing of bone density, and minimization of the risk of cancer development) [9]. Additionally, defatting improves protein interaction, organoleptic qualities, and acid hydrolysis of phenolic compounds [10-12].

Frying is one of the oldest processing and widely used technologies for many starch-based foods targeting crisp texture, aromatic flavor, and golden-brown color [13]. Frying is a complex process involving simultaneous heat, mass, and momentum transfers accompanied with a series of physical and chemical reactions [14]. During the frying process, heat is transferred from oil to fried foods leading to physical reactions (water evaporation and oil uptake) and chemical interactions within legume components (starch, reducing sugars, amino acids, and water) leading to structural changes [15]. The sensory quality represented in texture and flavor is a significant attribute which is always issued in the manufacturing of fried foods as it is related to processing conditions and variables, such as frying time, frying temperature, and moisture content [16].

The aim of this work was the assessment of physicochemical and sensory quality of barley-soybean chips targeting healthier snacks involving legume protein flours with enhanced properties. For achieving this aim, the impact of different substitution levels $(10,20$, and $30 \%)$ of defatted soybean (DSB) flour, frying temperatures $(150,170$, and $190^{\circ} \mathrm{C}$ ), and frying times $(60,90$, and $120 \mathrm{sec})$ on physicochemical characteristics (moisture, oil absorption, amylose, and amylopectin content), texture profile analysis (TPA), and sensorial acceptability of barley-soybean chips was studied.

\section{Materials and Methods}

2.1. Materials. Organic unhulled barley flour was obtained from Al-Hajraciyah Organic Farm, Saudi Organic Farming Association (SOFA), Kingdom of Saudi Arabia, while organic soybeans were obtained from Nature Oasis, origin: China, packed in Saudi Arabia.

2.2. Preparation of Defatted Soybean Flour. Clean soybean seeds were cracked in a rice sheller (6NF-9 (NF-400), China) and winnowed for hull removing. Cracked hulled soybeans were then milled in a hammer mill (Christy and Norris Ltd., England) with a speed of $8,000 \mathrm{rpm}$. Soybean flour was then defatted as described by Meyer [17], using hexane in a Soxhlet extractor for $6 \mathrm{~h} / 50-55^{\circ} \mathrm{C}$, dried at $40^{\circ} \mathrm{C} \pm 5 / 24 \mathrm{~h}$, and kept in polyethylene bags at $-4^{\circ} \mathrm{C}$.

\subsection{Preparation of Barley-Soybean Chips. Barley-soybean} chips were prepared according to Prakash et al. [18]. Based on preliminary sensory evaluation experiments, the production process was based on three treatments of barley substitution percentage with defatted soybean (DSB) flour $(10,20$, and $30 \%)$ as a high-protein source, three treatments of frying temperature $\left(150,170\right.$, and $\left.190^{\circ} \mathrm{C}\right)$, and three treatments of frying time $(60,90$, and $120 \mathrm{sec})$ which make 27 treatment combinations which were examined. Masa, the dough used for making chips, was prepared by mixing barley/soybean flour with distilled water $\left(41^{\circ} \mathrm{C}\right)(1000 \mathrm{~mL} /$ $1 \mathrm{~kg}$ of dry flour) in a pilot-scale mixer at low speed for $5 \mathrm{~min}$. The masa was allowed to rest in polyethylene bags for $10 \mathrm{~min}$. The masa was then sheeted through model S-18BNO 4458, Moline Machinery, Ltd., Duluth, MN, which was set at the lowest thickness (fourth lowest position: $0.2 \mathrm{~cm}$ ). The masa was then rapidly cut into $5 \mathrm{~cm}$ side squares with a blade cutter, and each square was then cut diagonally with a pizza cutter.

2.4. Frying Process. The frying process was accomplished in a thermostatically temperature-controlled fryer (Crown Co., XB5356 model, China) containing 1.5 L frying maize oil. The fresh oil was preheated to frying temperature for $30 \mathrm{~min}$ before the barley-soybean chips were fried. Samples were immersed into the frying oil basket at the desired temperature $\left(150,170\right.$, or $\left.190^{\circ} \mathrm{C}\right)$ for the desired frying time $(60,90$, and $120 \mathrm{sec})$. The samples were then immediately removed from oil, blotted with a tissue paper to remove excess oil on the surface, and allowed to cool at room temperature $\left(20^{\circ} \mathrm{C} \pm 2\right)$ before analyses.

2.5. Quality Characteristics of Barley-Soybean Chips. The effect of substitution percentages, frying temperatures, and frying times on main physicochemical quality characteristics of fresh barley-soybean chips was studied.

\subsubsection{Chemical Characteristics Affecting Chips' Quality.} The moisture content of the fried chips was determined by drying preweighed samples $(2.0 \mathrm{~g})$ in a hot air oven (130 ${ }^{\circ} \mathrm{C} \pm 1 / \mathrm{h}$ ), and the moisture content in percentage was calculated from loss of weight (AACC 44-15.02) [19]. Fat content (for oil absorption determination) was estimated by extracting the sample with petroleum ether, and percent fat was calculated according to AOAC 990.19 [20]. The amylose and amylopectin contents were determined by the method prescribed by Hoover and Ratnayake [21].

\subsubsection{Texture Profile Analysis of Barley-Soybean Chips.} Instrumental texture measurements were conducted at room temperature $\left(20^{\circ} \mathrm{C} \pm 2\right)$ using Texture Analyzer (CNS Farnell Com, UK). Immediately after deep-fat frying and cooling, uniaxial compression test, by using a $35 \mathrm{~mm}$-diameter plastic cylinder probe, was conducted on the barleysoybean chips after they were mounted over the platform. Samples were compressed to $30 \%$ strain at a constant speed of $25 \mathrm{~mm} / \mathrm{min}$ [22]. The texture of the barley-soybean chips was expressed as fracture force (highest peak followed by a hardness peak compression force (N) at target deformation), apparent modulus of elasticity or initial target modulus (sample rigidity that is the linear part of the force-deformation curve $(\mathrm{g} / \mathrm{sec})$ ), adhesiveness (negative force area during withdrawal $(\mathrm{g} / \mathrm{sec})$ ), and compressive energy (area under the curve for the compression that is the work $(\mathrm{g} / \mathrm{sec})$ required to attain deformation indicative of internal strength of bonds within the product) [23]. 
2.5.3. Organoleptic Properties of Barley-Soybean Chips. Fresh barley-soybean chips' samples were examined for sensory evaluation parameters, flavor, color, crispiness, mouthfeel, and overall acceptability, by twenty panelists (14 men and 6 women) in Nutrition and Food Science Department, Faculty of Science, Taif University, Kingdom of Saudi Arabia, under the supervision and agreement of the Institutional Committee of Taif University, Kingdom of Saudi Arabia [24]. The evaluation was done under normal white fluorescent lighting at a temperature of $20^{\circ} \mathrm{C} \pm 1$. Rating of samples was carried out using a nine-point scale where $1=$ nonexistent, imperceptible characteristic, and $9=$ too intense. Throughout panel sessions, panelists were instructed to rinse their mouths with water before testing each sample.

2.6. Statistical Analysis. Data were expressed as mean$\mathrm{s} \pm$ standard deviation (SD) and were analyzed using IBM SPSS Statistics 23 software program. Results were analyzed by multiple comparisons one-way analysis of variance (ANOVA) using Duncan's test where probability $p<0.05$ was considered statistically significant. Pearson's correlation coefficient analyses (Pearson's $r$ ) were performed to determine the relationships between parameters where +1 indicates a perfect positive relationship, -1 indicates a perfect negative relationship, $1-0.7$ indicates a strong relationship, $0.7-0.3$ indicates a moderate relationship, $0.3-0$ indicates a weak relationship, and 0 indicates no linear relationship [25].

\section{Results and Discussion}

\subsection{Quality Parameters of Barley-Soybean Chips}

3.1.1. Moisture Content and Oil Absorption. Moisture content is one of the most critical parameters as it affects the crisp texture that is a unique property of extruded snacks. Effects of frying temperature and frying time on the moisture content of different barley-soybean chips' blends are illustrated in Table 1. The moisture baseline of the masa was $3.61 \pm 0.75 \%$, while, after frying, it ranged from the highest of $2.2 \%$ in $10 \%$ DSB fried at $150^{\circ} \mathrm{C} / 60 \mathrm{sec}$ to the least of $1.4 \%$ in the same substitution percentage fried at $190^{\circ} \mathrm{C} /$ $120 \mathrm{sec}$. This result reflects the significant effect of temperature and time of chips' properties. Obtained results agreed with those of Yadav et al. [26]. The differences in the moisture content of barley-soybean chips for the treatments can be attributed to a moderate negative correlation $(r=-0.68,-0.66$, and -0.63$)$ between the frying temperature and frying time. An inverse relationship was detected when moisture contents of barley-soybean chips showed a significant decrease along with increasing frying temperature from $150^{\circ} \mathrm{C}$ to $190^{\circ} \mathrm{C}$ and frying time from 60 to $120 \mathrm{~min}$. On the contrary, higher moisture contents lead to hard and chewy in chips. These findings are in agreement with those of Cruz et al. [15], who reported that when the final moisture content is less than $2 \%$, it helps to obtain a crisp texture. Elevation of frying temperature and frying time engages the alteration of the moisture content in the chips, while nixtamalization (the process of cooking) results in a higher quality of cereal chips [15]. These effects were in consistency with decreased adhesiveness announced in texture profile analyses (Figure 1) and the sensory evaluation results that showed enhanced crispness of chips along with increased frying time.

Table 1 shows the effects of frying temperature and frying time on oil absorption of different barley-soybean chips' blends. The oil absorption showed an elevated pattern along with increased frying time, temperature, or DSB substitution percentage. The values of the oil absorption of barley-soybean chips with different treatments can be attributed to a moderate positive correlation $(r=0.44,0.45$, and 0.47$)$ between the frying temperature and frying time. Elevation in frying temperature from 150 to $190^{\circ} \mathrm{C}$ for frying time 60,90 , and 120 sec of $10 \%$ DSB barley-soybean chips showed significant increase in oil absorption from 29.25, 29.50, and $29.75 \%$ to $30.50,30.80$, and $31.10 \%$, respectively. Same patterns were observed in 20 and 30\% DSB barley-soybean chips. On the contrary, increasing DSB flour substitution percentage significantly increased the chips' moisture content and oil absorption. The ability to absorb oil of soybean flour may be due to a high protein content and particle size that may have contributed to the uptake of excess frying oil [9]. Oil absorption capacity increasing with increased soybean flour percentage in blends was reported by Oladeji Alamu et al. [10]. Oil enters chips through the water replacement mechanism, which involves changes in cellular structures and the formation of pores during frying, to fill some of the spaces created by induced dehydration [27].

3.1.2. Amylose and Amylopectin Contents of Barley-Soybean Chips. The results in Table 2 showed the influence of frying temperature and frying time on the amylose content of barley-soybean chips. Results revealed that the amylose content of barley-soybean chips was significantly increased along with elevated frying temperature, frying time, and DSB substitution percentage. The amylose values showed a moderate positive correlation ( $r=0.41,0.39$, and 0.37$)$ between the frying temperature and frying time. The highest recorded amylose value $(33.80 \%)$ was observed in barleysoybean chips fortified with $30 \%$ DSB at $190^{\circ} \mathrm{C}$ for $120 \mathrm{sec}$, whilst the lowest amylose content $(27.16 \%)$ was observed in barley-soybean chips with $10 \% \mathrm{DSB}$ at $150^{\circ} \mathrm{C}$ for $60 \mathrm{sec}$. The barley grain was reported to contain $25.39 \%$ amylose and $74.61 \%$ amylopectin [18]. Direct relationship was reported between apparent amylose, temperature, and moisture content [28]. Amylose has a crucial role in oil absorption of starch during frying, and more amylose molecules provide more hydrophobic helical cavities available for lipids [13], which supports the oil absorption results raised in Table 1.

The amylopectin content of barley-soybean chips with $10.0 \%$ DSB flour recorded the highest percentage $(72.83 \%)$ at $150^{\circ} \mathrm{C}$ for $60 \mathrm{sec}$, while the barley-soybean chips with $30 \%$ DSB substitution recorded the lowest percentage (66.20\%) at $190^{\circ} \mathrm{C}$ for $120 \mathrm{sec}$ (Table 2). It showed an opposite pattern to the amylose content in the same values but with a negative correlation ( $r=-0.41,-0.39$, and -0.37$)$ between the frying 
TABLE 1: Effects of frying temperature and frying time on the moisture content and oil absorption of barley-soybean chips.

\begin{tabular}{|c|c|c|c|c|}
\hline \multirow{2}{*}{ DSB substitution (\%) } & \multirow{2}{*}{ Frying temperature $\left({ }^{\circ} \mathrm{C}\right)$} & \multicolumn{3}{|c|}{ Frying time (sec) } \\
\hline & & 60 & 90 & 120 \\
\hline \multicolumn{5}{|l|}{ Moisture content } \\
\hline \multirow[t]{4}{*}{ ( } & 150 & $2.20 \pm 0.24^{\mathrm{ab}}$ & $2.10 \pm 0.18^{\mathrm{b}}$ & $2.00 \pm 0.15^{\mathrm{b}}$ \\
\hline & 170 & $1.90 \pm 0.21^{\mathrm{c}}$ & $180 \pm 0.11^{\mathrm{cd}}$ & $1.70 \pm 0.14^{\mathrm{b}}$ \\
\hline & 190 & $1.80 \pm 0.14^{\mathrm{c}}$ & $1.50 \pm 0.14^{\mathrm{d}}$ & $1.40 \pm 0.12^{\mathrm{d}}$ \\
\hline & 150 & $2.30 \pm 0.23^{\mathrm{a}}$ & $2.20 \pm 0.19^{\mathrm{ab}}$ & $2.10 \pm 0.21^{\mathrm{b}}$ \\
\hline \multirow{3}{*}{20} & 170 & $2.00 \pm 0.18^{\mathrm{b}}$ & $1.90 \pm 0.15^{\mathrm{c}}$ & $1.80 \pm 0.17^{\mathrm{c}}$ \\
\hline & 190 & $1.90 \pm 0.16^{\mathrm{c}}$ & $1.70 \pm 0.12^{\mathrm{cd}}$ & $1.60 \pm 0.13^{\mathrm{d}}$ \\
\hline & 150 & $2.50 \pm 0.21^{\mathrm{a}}$ & $2.40 \pm 0.21^{\mathrm{a}}$ & $2.30 \pm 0.26^{\mathrm{a}}$ \\
\hline \multirow{2}{*}{30} & 170 & $2.30 \pm 0.24^{\mathrm{a}}$ & $2.25 \pm 0.24^{\mathrm{ab}}$ & $2.15 \pm 0.26^{\mathrm{ab}}$ \\
\hline & 190 & $2.20 \pm 0.22^{\mathrm{ab}}$ & $2.15 \pm 0.26^{\mathrm{ab}}$ & $2.10 \pm 0.21^{\mathrm{b}}$ \\
\hline Pearson's correlation $r$ & & -0.680 & -0.666 & -0.633 \\
\hline \multicolumn{5}{|l|}{ Oil absorption } \\
\hline \multirow{4}{*}{10} & 150 & $29.25 \pm 2.14^{\mathrm{d}}$ & $29.50 \pm 2.14^{\mathrm{d}}$ & $29.75 \pm 2.16^{\mathrm{d}}$ \\
\hline & 170 & $30.00 \pm 2.18^{c}$ & $30.22 \pm 2.18^{c}$ & $30.40 \pm 2.52^{c}$ \\
\hline & 190 & $30.50 \pm 2.45^{\mathrm{c}}$ & $30.80 \pm 2.41^{\mathrm{c}}$ & $31.10 \pm 2.49^{\mathrm{b}}$ \\
\hline & 150 & $30.30 \pm 2.35^{c}$ & $30.40 \pm 2.68^{c}$ & $30.55 \pm 2.46^{\mathrm{c}}$ \\
\hline \multirow{3}{*}{20} & 170 & $30.65 \pm 2.37^{\mathrm{c}}$ & $30.80 \pm 2.57^{\mathrm{c}}$ & $30.95 \pm 2.74^{\mathrm{c}}$ \\
\hline & 190 & $31.15 \pm 2.49^{\mathrm{b}}$ & $31.25 \pm 2.49^{\mathrm{b}}$ & $31.35 \pm 2.61^{\mathrm{b}}$ \\
\hline & 150 & $31.45 \pm 2.51^{\mathrm{b}}$ & $31.65 \pm 2.94^{\mathrm{b}}$ & $31.80 \pm 2.38^{\mathrm{b}}$ \\
\hline \multirow{2}{*}{30} & 170 & $31.95 \pm 2.65^{\mathrm{b}}$ & $32.20 \pm 2.76^{\mathrm{a}}$ & $32.35 \pm 3.12^{\mathrm{a}}$ \\
\hline & 190 & $32.45 \pm 2.17^{\mathrm{a}}$ & $32.65 \pm 3.01^{\mathrm{a}}$ & $32.85 \pm 3.28^{\mathrm{a}}$ \\
\hline Pearson's correlation $r$ & & 0.448 & 0.457 & 0.472 \\
\hline
\end{tabular}

Data represent means \pm SD. Means followed by different superscript letters in each column are significantly different $(p<0.05)$. DSB: defatted soybean; Pearson's correlation $r$ : Pearson's correlation coefficient.

temperature and frying time. The significant decrease in the amylopectin content along with increased frying temperature, frying time, and DSB substitution percentage was previously reported by several authors due to heat stress [29-31]. The amylose-to-amylopectin ratio is one of the most important factors affecting the physicochemical and sensorial properties, processing performance, and functionality of starch [13]. Amylopectin is a glucose polymer in a large number of short-chain branches organized in semicrystalline granules [32]. This may introduce an explanation of the decreased scores of mouthfeel of barleysoybean chips in sensory evaluation results illustrated in Figure 2, along with the declined amylopectin content.

3.2. Texture Profile Analysis (TPA). The effect of treatments on texture profile analysis (TPA) of barley-soybean chips is presented in Figures 1(a)-1(d). Obtained results indicated a significant variation in all texture indices among different blends of barley-soybean chips. The hardness of barleysoybean chips (Figure 1(a)) was significantly increased by increasing the substitution percentage of DSB flour, whilst frying time and frying temperature showed an adverse effect on chips' hardness. The highest hardness value $(12.57 \mathrm{~N})$ was recorded for barley-soybean chips prepared with 30\% DSB flour at $150^{\circ} \mathrm{C}$ fried for $60 \mathrm{sec}$ followed by chips prepared with $20 \% \mathrm{DSB}$ flour at $150^{\circ} \mathrm{C}$ for $60 \mathrm{sec}(11.72 \mathrm{~N})$ and then barley-soybean chips prepared with $10 \%$ DSB flour $(10.82 \mathrm{~N})$ at $150^{\circ} \mathrm{C}$ for $60 \mathrm{sec}$. An opposite pattern was observed for texture profile parameters elasticity and adhesiveness, while compression energy did not show any significant changes between different DSB substitution percentages in Figures $1(\mathrm{~b})-1(\mathrm{~d}))$. Modulus of elasticity is connected to the firmness of the sample. These results may be due to the intensive water evaporation during deep frying that promotes the expansion of the food matrix and allows oil absorption [32]. During the frying process, heat is transferred from oil to fried foods accompanied by mass transfer (water evaporation and oil uptake). Apart from heat, mass, and momentum transfers, chemical constituents such as starch, reducing sugars, amino acids, and water within the plant tissue react with each other during frying, and physical reactions occur accompanied by structural changes that consequently increase hardness [14]. Additionally, less force and work values were due to the foamy structure created by soybean flour in fried products along with the increasing level of DSB substitution. As the hardness increases, the elasticity and adhesiveness decrease for more crispness feeling which was observed in sensory evaluation (Figures 2-4).

Frying time and frying temperature were inversely proportional with assessed texture parameter values. The elasticity of barley-soybean chips ranged from 124.8 to $940.0 \mathrm{~g} / \mathrm{sec}$ at $10.0 \%$ DSB and 110.4 to $775.0 \mathrm{~g} / \mathrm{sec}$ at $20.0 \%$ DSB flour to reach 85.4 to $709.9 \mathrm{~g} / \mathrm{sec}$ in $30 \%$ DSB products. Adhesiveness indicates the quantity of work required for controlling the attractive power among the surface of the product and the material with which in contact [33]. The least adhesiveness was observed in $30 \%$ DSB flour fried at 170 and $190^{\circ} \mathrm{C}$ for 90 and $120 \mathrm{sec}$. Frying enhances the interactions between oil and fried food leading to increased oil absorption (Table 1). Surface-active agents can increase 


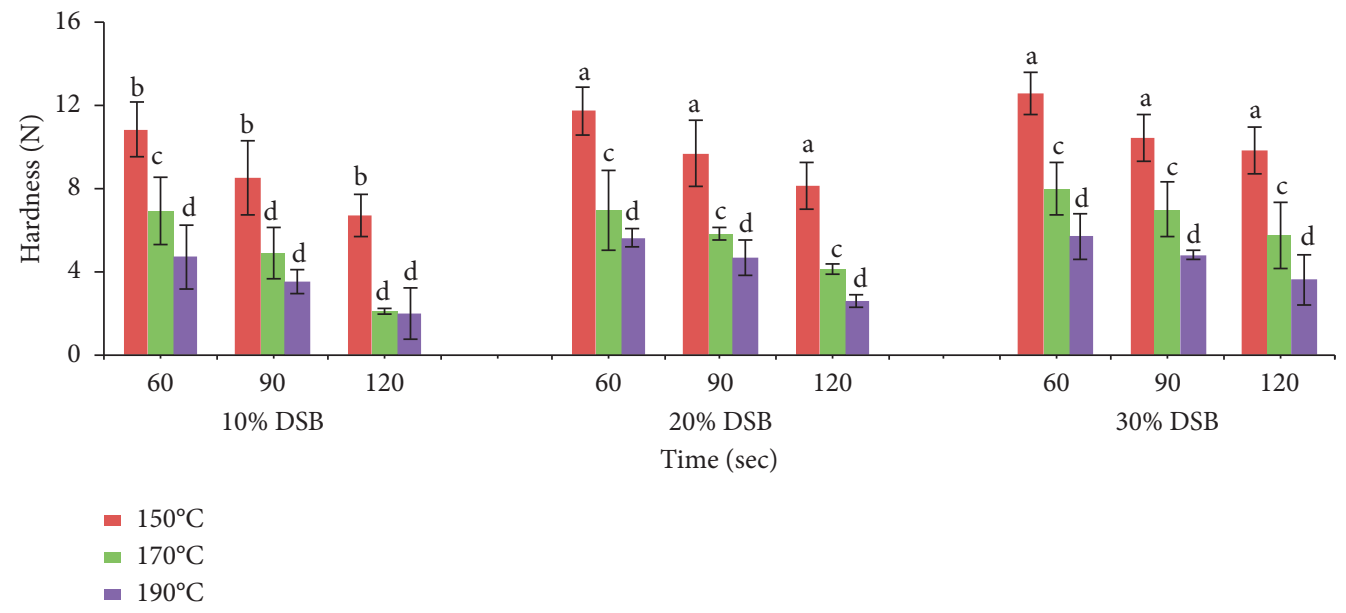

(a)

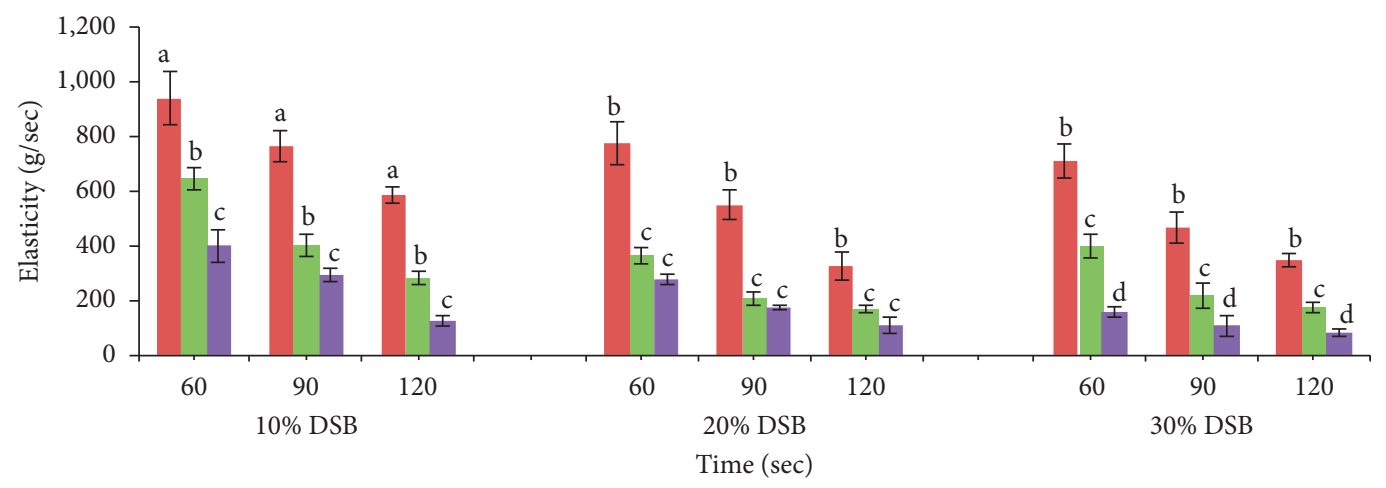

- $150^{\circ} \mathrm{C}$

- $170^{\circ} \mathrm{C}$

- $190^{\circ} \mathrm{C}$

(b)

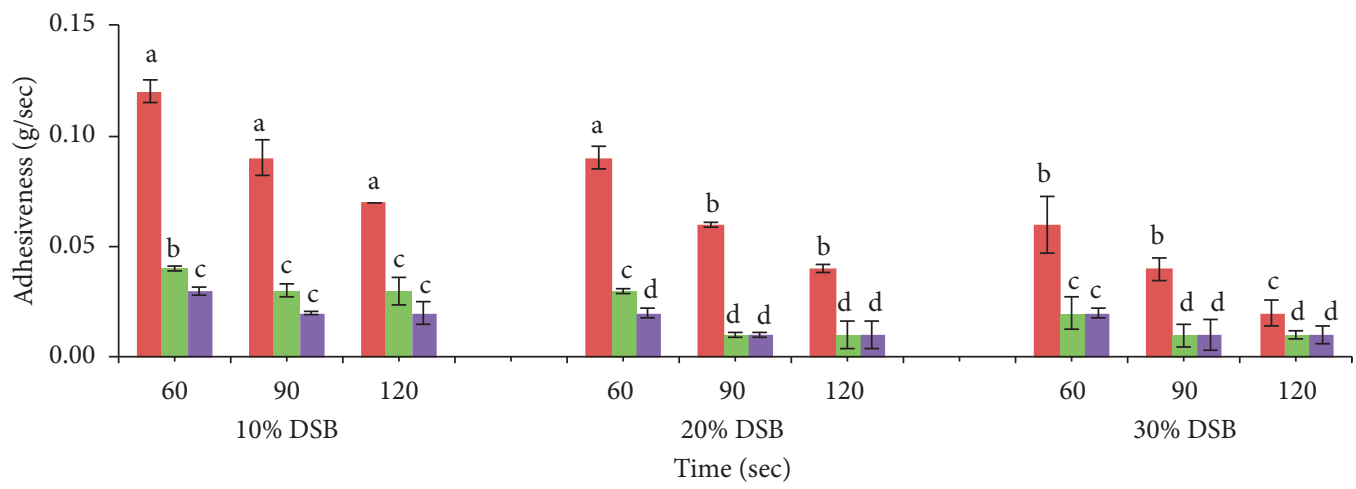

- $150^{\circ} \mathrm{C}$

- $170^{\circ} \mathrm{C}$

- $190^{\circ} \mathrm{C}$

(c)

Figure 1: Continued. 


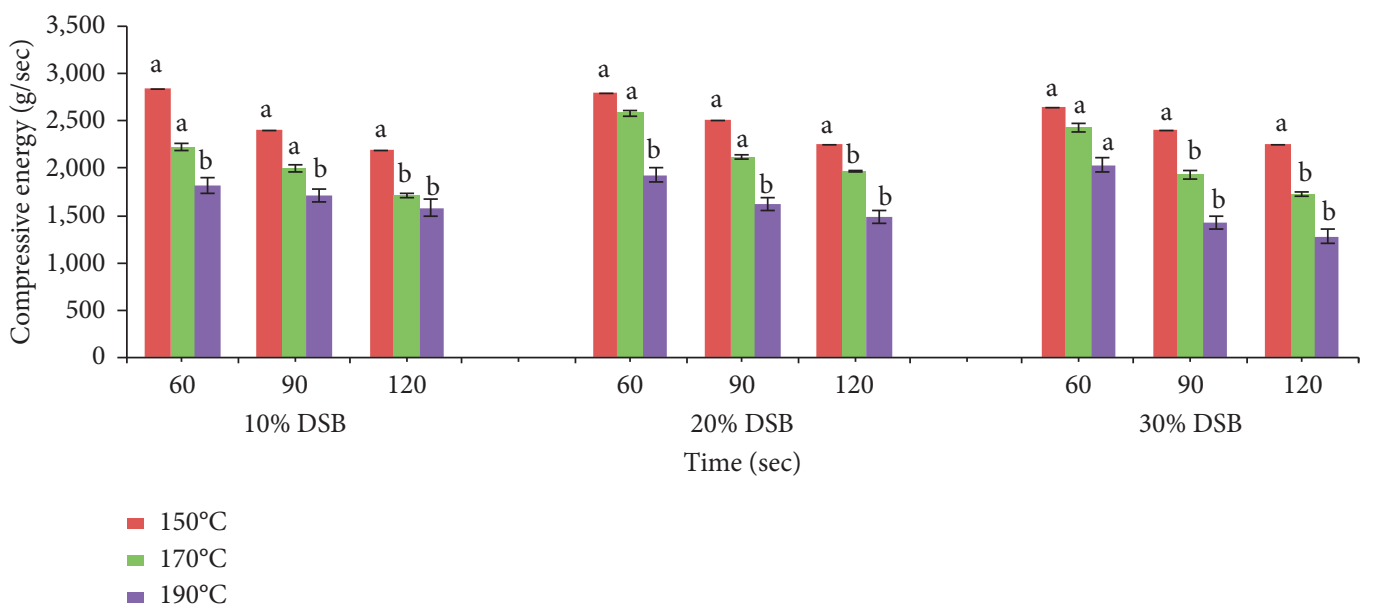

(d)

FIgURE 1: Effect of treatments on the texture profile analysis (TPA) of barley-soybean chips. (a) Hardness (N). (b) Elasticity (g/sec). (c) Adhesiveness $(\mathrm{g} / \mathrm{sec})$. (d) Compression energy. Data represent the means \pm SD. Means with different superscript letters are significantly different $(p<0.05)$. DSB: defatted soybean.

TABLE 2: Effects of frying temperature and frying time on the amylose content of barley-soybean chips.

\begin{tabular}{|c|c|c|c|c|}
\hline \multirow{2}{*}{ DSB substitution (\%) } & \multirow{2}{*}{ Frying temperature $\left({ }^{\circ} \mathrm{C}\right)$} & \multicolumn{3}{|c|}{ Frying time (sec) } \\
\hline & & 60 & 90 & 120 \\
\hline \multicolumn{5}{|l|}{ Amylose content } \\
\hline \multirow[t]{4}{*}{ 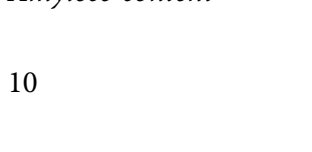 } & 150 & $27.16 \pm 1.90^{\mathrm{e}}$ & $27.50 \pm 2.11^{\mathrm{e}}$ & $28.00 \pm 2 / 18^{\mathrm{e}}$ \\
\hline & 170 & $28.35 \pm 2.04^{\mathrm{d}}$ & $28.74 \pm 2.17^{\mathrm{d}}$ & $29.07 \pm 2.27^{\mathrm{d}}$ \\
\hline & 190 & $29.44 \pm 2.15^{\mathrm{d}}$ & $29.82 \pm 2.21^{\mathrm{d}}$ & $30.11 \pm 2.23^{c}$ \\
\hline & 150 & $29.43 \pm 2.35^{\mathrm{d}}$ & $29.77 \pm 2.25^{\mathrm{d}}$ & $30.01 \pm 2.61^{\mathrm{c}}$ \\
\hline \multirow{3}{*}{20} & 170 & $30.31 \pm 2.58^{\mathrm{c}}$ & $30.86 \pm 2.19^{c}$ & $31.22 \pm 2.43^{\mathrm{b}}$ \\
\hline & 190 & $31.68 \pm 2.67^{\mathrm{b}}$ & $32.12 \pm 2.28^{\mathrm{b}}$ & $32.43 \pm 2.57^{\mathrm{b}}$ \\
\hline & 150 & $31.90 \pm 2.49^{\mathrm{b}}$ & $32.45 \pm 2.94^{\mathrm{b}}$ & $32.95 \pm 2.62^{\mathrm{b}}$ \\
\hline \multirow{2}{*}{30} & 170 & $32.55 \pm 3.14^{\mathrm{a}}$ & $33.00 \pm 3.16^{\mathrm{a}}$ & $33.50 \pm 3.42^{\mathrm{a}}$ \\
\hline & 190 & $33.15 \pm 3.12^{\mathrm{a}}$ & $33.40 \pm 3.25^{\mathrm{a}}$ & $33.80 \pm 3.16^{\mathrm{a}}$ \\
\hline Pearson's correlation $r$ & & 0.413 & 0.398 & 0.377 \\
\hline \multicolumn{5}{|l|}{ Amylopectin content } \\
\hline \multirow[t]{4}{*}{ P 1} & 150 & $72.83 \pm 3.45^{\mathrm{a}}$ & $72.49 \pm 4.35^{\mathrm{a}}$ & $71.90 \pm 4.39^{\mathrm{ab}}$ \\
\hline & 170 & $71.64 \pm 3.68^{\mathrm{ab}}$ & $71.25 \pm 4.16^{\mathrm{ab}}$ & $70.93 \pm 4.16^{\mathrm{ab}}$ \\
\hline & 190 & $70.55 \pm 3.12^{\mathrm{ab}}$ & $70.17 \pm 3.84^{\mathrm{b}}$ & $69.88 \pm 3.48^{\mathrm{ab}}$ \\
\hline & 150 & $70.56 \pm 3.69^{\mathrm{ab}}$ & $70.22 \pm 3.68^{\mathrm{ab}}$ & $69.98 \pm 3.59^{c}$ \\
\hline \multirow{3}{*}{20} & 170 & $69.68 \pm 3.11^{c}$ & $69.13 \pm 4.19^{c}$ & $68.77 \pm 2.97^{\mathrm{c}}$ \\
\hline & 190 & $68.31 \pm 3.19^{c}$ & $67.87 \pm 4.28^{\mathrm{d}}$ & $67.57 \pm 3.28^{\mathrm{d}}$ \\
\hline & 150 & $68.10 \pm 2.95^{\mathrm{c}}$ & $67.55 \pm 3.79^{d}$ & $67.05 \pm 3.81^{\mathrm{d}}$ \\
\hline \multirow{2}{*}{30} & 170 & $67.45 \pm 4.12^{\mathrm{d}}$ & $67.00 \pm 3.81^{\mathrm{d}}$ & $66.50 \pm 3.93^{\mathrm{e}}$ \\
\hline & 190 & $66.85 \pm 2.61^{\mathrm{e}}$ & $66.60 \pm 2.99^{\mathrm{e}}$ & $66.20 \pm 3.37^{\mathrm{e}}$ \\
\hline Pearson's correlation $r$ & & -0.414 & -0.399 & -0.373 \\
\hline
\end{tabular}

Data represent means \pm SD. Means followed by different superscript letters in each column are significantly different $(p<0.05)$. DSB: defatted soybean; Pearson's correlation $r$ : Pearson's correlation coefficient.

the foaming tendency of oil and reduce the interfacial tension leading to the increase of surface hydrophobicity, leading to less elasticity and adhesiveness [14].

3.3. Sensory Evaluation of Barley-Soybean Chips. Sensory evaluation results of barley-soybean chips' attributes at different frying times $(60,90$, and $120 \mathrm{sec})$ with different DSB substitution percentages $(10,20$, and $30 \%)$ are exhibited in Figures 2-4, respectively. Obtained results revealed that the most preferred chips based on sensory evaluation were barley-soybean chips with $10 \%$ DSB fried at 150 and $170^{\circ} \mathrm{C}$ (Figures 4(a) and 4(b)) with no observed effects of frying time. At the same conditions of frying temperature and frying time, increased DSB flour substitution percentage scored less values of flavor, color, crispness, mouthfeel, and 


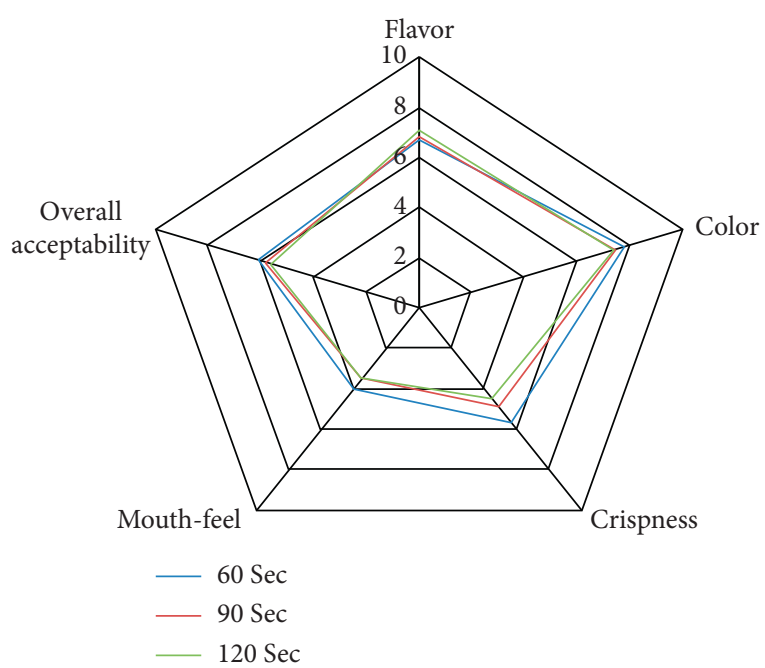

(a)

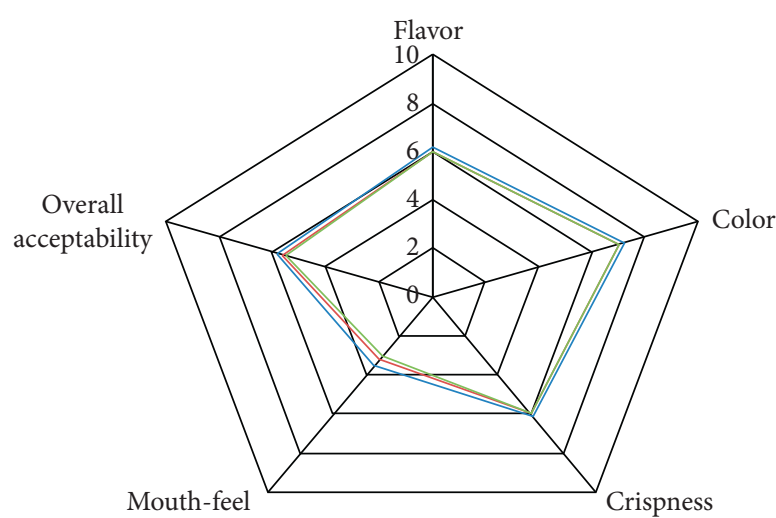

$60 \mathrm{Sec}$

- $90 \mathrm{Sec}$

$120 \mathrm{Sec}$

(b)

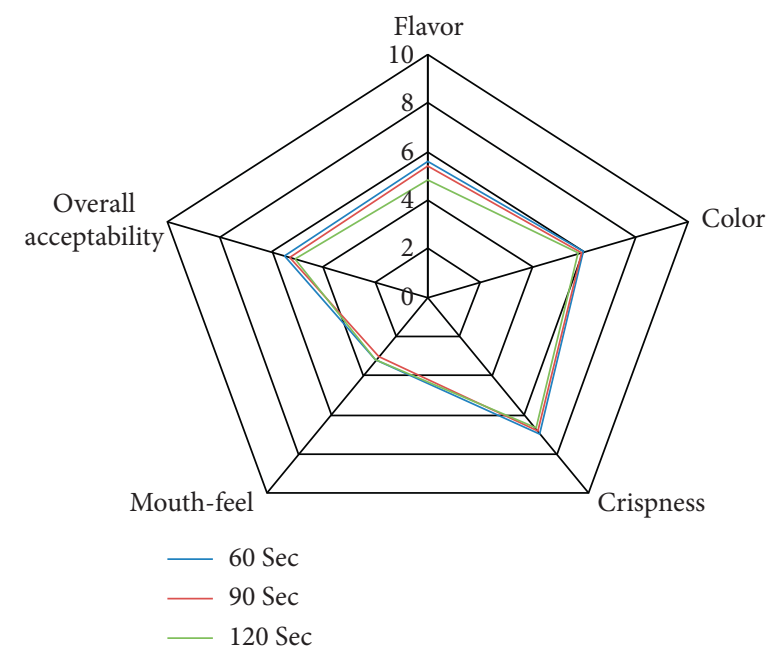

(c)

FIGURE 2: Sensory evaluation of barley-soybean chips (30\% DSB) at different frying times $\left(60,90\right.$, and 120 sec). (a) Frying temperature $150^{\circ} \mathrm{C}$ (CF). (b) Frying temperature $170^{\circ} \mathrm{C}$. (c) Frying temperature $190^{\circ} \mathrm{C}$. DSB: defatted soybean.

consequently overall acceptability. This could be explained as soybean proteins are rich in lysine residues which are highly sensible to the Maillard reaction. Nutritional impairment of protein, as a consequence of the destruction of its essential amino acids or the decrease in their bioavailability, is one of the most known nutritional implications of the Maillard reaction [12].

Accordingly, barley-soybean chips with $30 \%$ DSB fried at 170 and $190^{\circ} \mathrm{C}$ received the least scores of all sensory parameters. Color is a significant quality parameter of fried snacks concerning consumer understanding and frequently is the foundation for their chosen fried snacks. Increased frying temperature or long frying time during the deepfrying process initiates nonenzymatic browning reactions (Millard reaction) that affect products' color [15]. Maillard reaction leads to the formation of brown polymers called melanoidins. They affect the color (as well as flavor) of heattreated samples indicating the extent of the Maillard reaction. Gradual changes in color intensity starting with preferable cream to dark golden brown along with stages of the Maillard reaction should be controlled for accepted products. Another hypothesis expects that thermal oxidation of oil may also contribute to the color of the fried products [10].

Crispness is detected during a collection of different key texture advantages for snack products. Crispness is also connected to mastication which is based on break in crisp materialsthat generate sound participation in crispness sensation [34]. Increased crispness of barley-soybean chips showed to be related with increased frying temperature. It may be due to the spongy porous structures accompanied with losing moisture that plays a significant function in crispness [35]. These results are correlated with the moisture content (Table 1). Panelists experienced a fatty mouthfeel when the temperature and frying time increased, which may be due to greater oil absorption as indicated in Table 1 . 


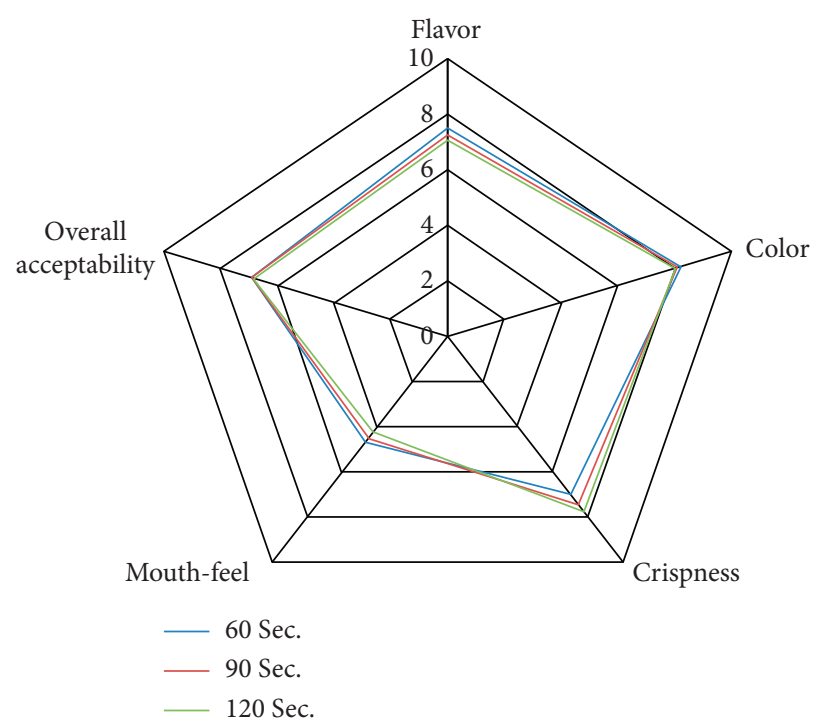

(a)

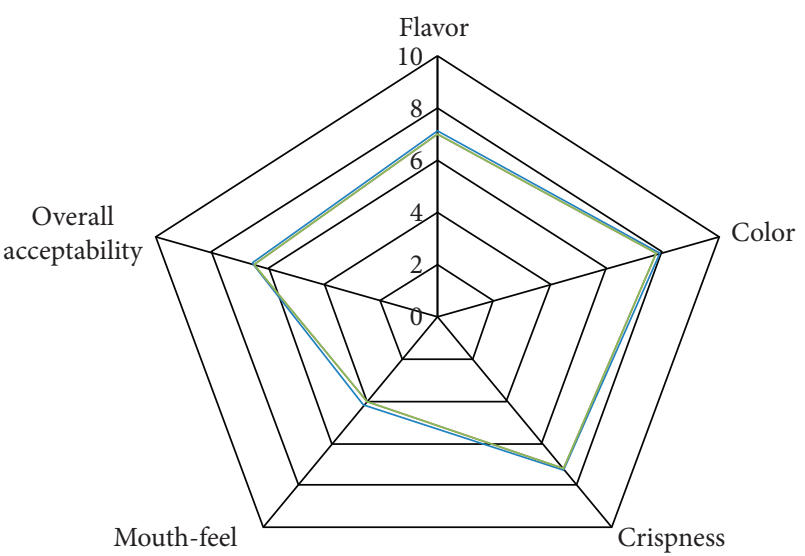

$60 \mathrm{Sec}$

- $90 \mathrm{Sec}$

$120 \mathrm{Sec}$

(b)

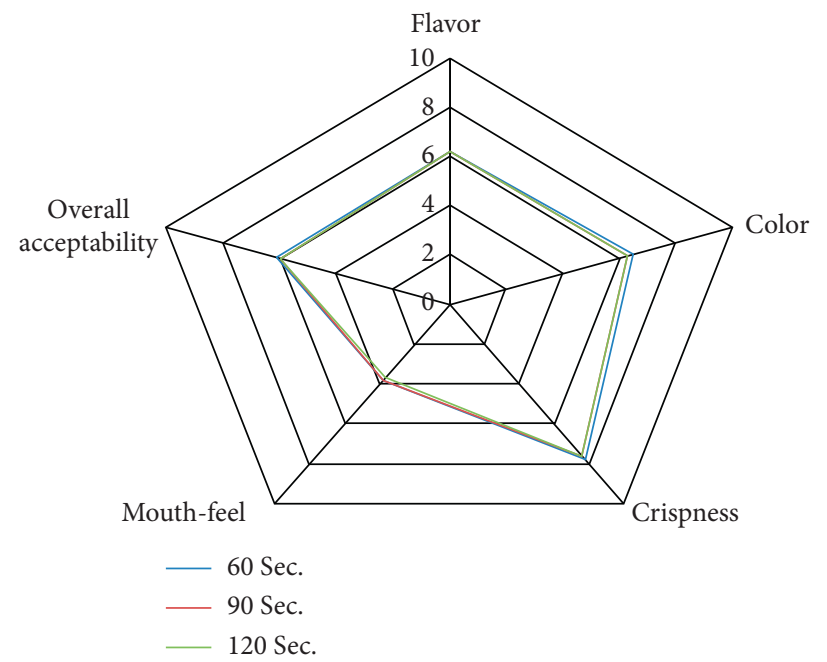

(c)

FiguRE 3: Sensory evaluation of barley-soybean chips (20\% DSB) at different frying times $\left(60,90\right.$, and 120 sec). (a) Frying temperature $150^{\circ} \mathrm{C}$ (CF). (b) Frying temperature $170^{\circ} \mathrm{C}$. (c) Frying temperature $190^{\circ} \mathrm{C}$. DSB: defatted soybean.

Although less adhesiveness (Figure 1(c)) is correlated with enhanced mouthfeel [23], the greasy feeling caused the mouthfeel scores to decrease.

To sum sensory attributes' evaluation, panelists preferred barley-soybean chips at level 10 and 20\% DSB substitution fried at 150 and $170^{\circ} \mathrm{C}$ as increased substitution percentage along with elevated frying temperature and frying time caused undesirable attributes either due to progressed Maillard reaction or excess oil absorption. These results are in agreement with what Oladeji Alamu et al. reported [10]. 


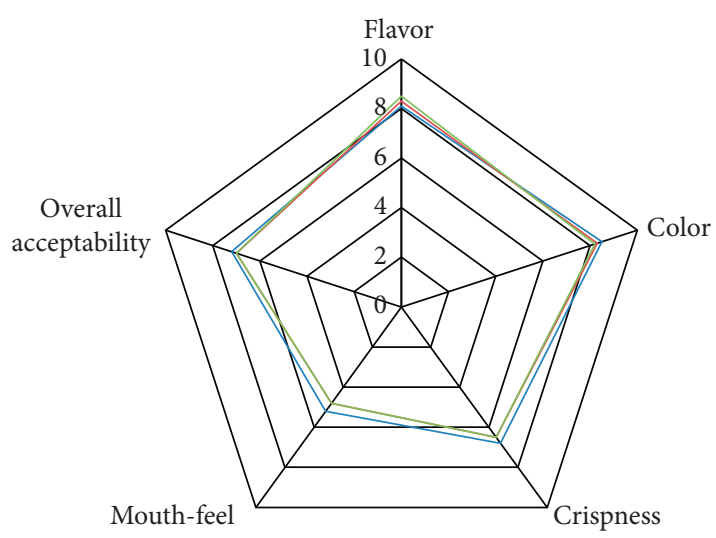

$-60 \mathrm{Sec}$.
$-90 \mathrm{Sec}$.
$-120 \mathrm{Sec}$.

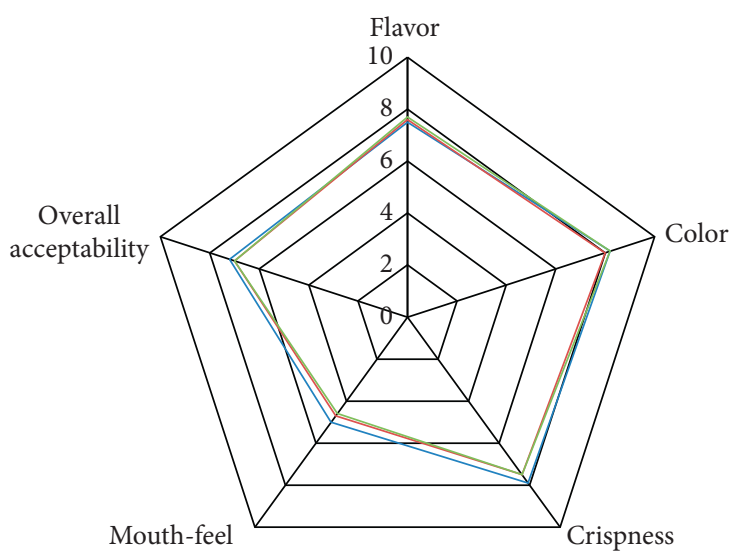

$-60 \mathrm{Sec}$.
$-90 \mathrm{Sec}$.
$-120 \mathrm{Sec}$

(a)

(b)

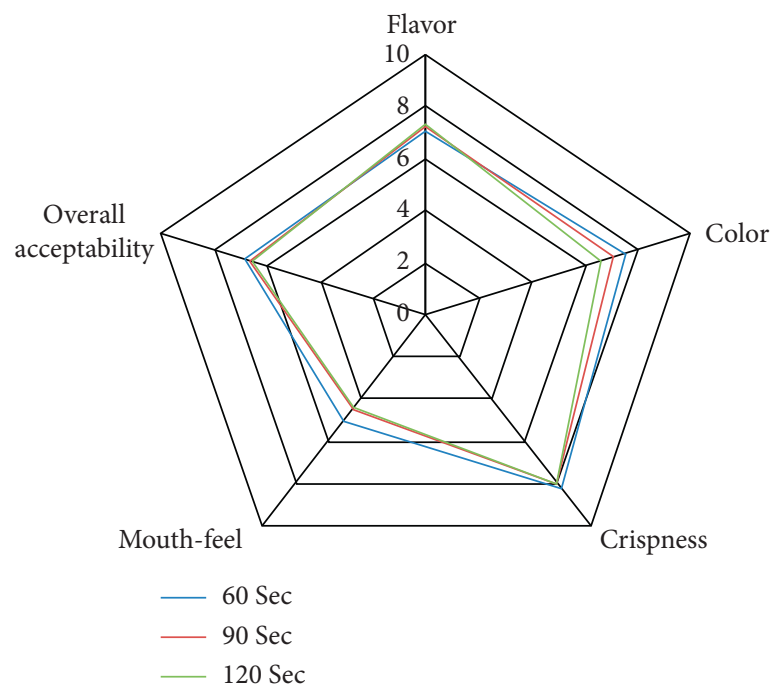

(c)

Figure 4: Sensory evaluation of barley-soybean chips (10\% DSB) at different frying times (60, 90, and 120 sec). (a) Frying temperature $150^{\circ} \mathrm{C}$ (CF). (b) Frying temperature $170^{\circ} \mathrm{C}$. (c) Frying temperature $190^{\circ} \mathrm{C}$. DSB: defatted soybean.

\section{Conclusion}

Evaluation of the effects of different substitution levels (10, 20, and $30 \%$ ) of defatted soybean (DSB) flour, frying temperatures $\left(150,170\right.$, and $\left.190^{\circ} \mathrm{C}\right)$, and frying times $(60,90$, and $120 \mathrm{sec}$ ) on physicochemical characteristics of barley-soybean chips revealed that the moisture content was substituted by oil absorption and amylose and amylopectin contents along with the increase in testing factors. These influences were reflected on the texture profile analysis (TPA) of barley-soybean chips resulting in increased hardness in parallel with decreased elasticity and adhesiveness. This in turn consequently affected sensorial acceptability to reveal that the most preferable substitution level was 10 and $20 \%$ DSB that were fried at temperature which did not exceed $170^{\circ} \mathrm{C}$. These findings encourage snacks production with acceptable substitution levels of legume protein flour while maintaining consumer satisfaction which is the main pillar for innovative food preparations.

\section{Data Availability}

The supporting data are available from the corresponding author upon request.

\section{Conflicts of Interest}

The authors declare no conflicts of interest with respect to the research, authorship, and/or publication of this article.

\section{Authors' Contributions}

HAA and AMGD conceptualized the study, provided the methodology, investigated the study, and visualized the 
study. HAA prepared and wrote the original draft. AMGD wrote, reviewed, and edited the final version of the manuscript. Both authors read and agreed to the published version of the manuscript.

\section{References}

[1] R. E. Blaine, A. Kachurak, K. K. Davison, R. Klabunde, and J. O. Fisher, "Food parenting and child snacking: a systematic review," International Journal of Behavioral Nutrition and Physical Activity, vol. 14, no. 1, p. 146, 2017.

[2] F. Bastami, F. Zamani-Alavijeh, and F. Mostafavi, "Factors behind healthy snack consumption at school among highschool students: a qualitative study," BMC Public Health, vol. 19, no. 1, pp. 1342-1347, 2019.

[3] A. Taniguchi, N. Kyogoku, H. Kimura, T. Kondo, K. Nagao, and R. Kobayashi, "Antioxidant capacity of tempura deepfried products prepared using barley, buckwheat, and job's tears flours," Foods, vol. 9, no. 9, p. 1246, 2020.

[4] M. Potter, A. Vlassopoulos, and U. Lehmann, "Snacking recommendations worldwide: a scoping review," Advances in Nutrition, vol. 9, no. 2, pp. 86-98, 2018.

[5] G. Šimić, A. Lalić, and D. Horvat, "Production and analysis of the flour from the hull-less barley," Journal of Food Measurement and Characterization, vol. 15, pp. 2679-2687, 2021.

[6] A. Pswarayi, F. A. Van Eeuwijk, S. Ceccarelli et al., "Barley adaptation and improvement in the Mediterranean basin," Plant Breeding, vol. 127, no. 6, pp. 554-560, 2008.

[7] L. Lahouar, F. Ghrairi, and A. El Arem, "Biochemical composition and nutritional evaluation of barley rihane (hordeum vulgare L.)." African Journal of Traditional, Complementary, and Alternative Medicines: AJTCAM, vol. 14, no. 1, pp. 310-317, 2017.

[8] Y. Zeng, X. Pu, J. Du, and X. Yang, "Molecular mechanism of functional ingredients in barley to combat human chronic diseases," Oxidative Medicine and Cellular Longevity, vol. 2020, Article ID 3836172, 26 pages, 2020.

[9] G. Aiello, R. Pugliese, and L. Rueller, "Assessment of the physicochemical and conformational changes of ultrasounddriven proteins extracted from soybean okara byproduct," Foods, vol. 10, no. 3, 2021.

[10] E. Oladeji Alamu, B. Maziya-Dixon, B. Maziya-Dixon, B. Olaniyan, N. Pheneas, and D. Chikoye, "Evaluation of nutritional properties of cassava-legumes snacks for domestic consumption-consumer acceptance and willingness to pay in Zambia," AIMS Agriculture and Food, vol. 5, no. 3, pp. 500-520, 2020.

[11] M. Amjid, A. Shehzad, S. Hussain, M. Shabbir, M. Khan, and M. Shoaib, "A comprehensive review on wheat flour dough rheology," Pakistan Journal of Food Sciences, vol. 23, no. 2, pp. 105-123, 2013.

[12] S. Zilić, B. A. Mogol, G. Akıllığlu, A. Serpen, N. Delić, and V. Gökmen, "Effects of extrusion, infrared and microwave processing on Maillard reaction products and phenolic compounds in soybean," Journal of the Science of Food and Agriculture, vol. 94, no. 1, pp. 45-51, 2014.

[13] L. Chen, D. J. McClements, H. Zhang, Z. Zhang, Z. Jin, and Y. Tian, "Impact of amylose content on structural changes and oil absorption of fried maize starches," Food Chemistry, vol. 287, no. 2018, pp. 28-37, 2019.

[14] Z. Xu, S. Y. Leong, M. Farid, P. Silcock, P. Bremer, and I. Oey, "Understanding the frying process of plant-based foods pretreated with pulsed electric fields using frying models," Foods, vol. 9, no. 7, p. 949, 2020.
[15] G. Cruz, J. P. Cruz-Tirado, K. Delgado et al., "Impact of predrying and frying time on physical properties and sensorial acceptability of fried potato chips," Journal of Food Science \& Technology, vol. 55, no. 1, pp. 138-144, 2018.

[16] M. BahramParvar, T. Mohammadi Moghaddam, and S. M. A. Razavi, "Effect of deep-fat frying on sensory and textural attributes of pellet snacks," Journal of Food Science and Technology, vol. 51, no. 12, pp. 3758-3766, 2014.

[17] E. W. Meyer, "Oilseed protein concentrates and isolates," Journal of the American Oil Chemists Society, vol. 48, no. 9, pp. 484-488, 1971.

[18] J. Prakash, H. R. Naik, S. Z. Hussain, and B. Singh, "Effect of processing conditions on the quality characteristics of barley chips," Journal of Food Science \& Technology, vol. 52, no. 1, pp. 294-302, 2015.

[19] AACC Approved Methods of Analysis, The Association, AACC Approved Methods of Analysis, St. Paul, MN, USA, 2000.

[20] AOAC, Official Methods of Analysis, Association of Official Analytical Chemists International., Maryland, MA, USA, 2012.

[21] K. Hoover and M. Ratnayake, Standard Method of Analysis, Kalyani Publishers, New Delhi, India, 2001.

[22] G. W. Halek, S. W. Paik, and K. L. B. Chang, "The effect of moisture content on mechanical properties and texture profile parameters of corn meal extrudates," Journal of Texture Studies, vol. 20, no. 1, pp. 43-56, 1989.

[23] E. H.-J. Kim, V. K. Corrigan, D. I. Hedderley, L. Motoi, A. J. Wilson, and M. P. Morgenstern, "Predicting the sensory texture of cereal snack bars using instrumental measurements," Journal of Texture Studies, vol. 40, no. 4, pp. 457-481, 2009.

[24] Y. Liu, F. Hsieh, H. Heymann, and H. E. Huff, "Effect of process conditions on the physical and sensory properties of extruded oat-corn puff," Journal of Food Science, vol. 65, no. 7, pp. 1253-1259, 2000.

[25] B. Ratner, "The correlation coefficient: its values range between $+1 /-1$, or do they?" Journal of Targeting, Measurement and Analysis for Marketing, vol. 17, no. 2, pp. 139-142, 2009.

[26] U. Yadav, R. R. B. Singh, and S. Arora, "Evaluation of quality changes in nutritionally enriched extruded snacks during storage," Journal of Food Science \& Technology, vol. 55, no. 10, pp. 3939-3948, 2018.

[27] N. Ziphorah, N. Tilahun, S. Workneh, and M. Siwela, "Effect of low-temperature long-time and high-temperature shorttime blanching and frying treatments on the French fry quality of six Irish potato cultivars," Journal of Food Science \& Technology, vol. 54, no. 2, pp. 507-517, 2017.

[28] M. J. Missão, R. Cristina, and F. Bonomo, "The impact of heatmoisture treatment on the properties of musa paradisiaca $\mathrm{L}$. Starch and optimization of process variables," Food Technology and Biotechnology, vol. 56, no. 4, pp. 506-515, 2018.

[29] S. Reyniers, N. Ooms, and J. A. Delcour, "Transformations and functional role of starch during potato crisp making: a review," Journal of Food Science, vol. 85, no. 12, pp. 4118-4129, 2020.

[30] X. Fan, Y. Li, Y. Zhu et al., "Characterization of physicochemical qualities and starch structures of two indica rice varieties tolerant to high temperature during grain filling," Journal of Cereal Science, vol. 93, p. 102966, 2020.

[31] A. Y. M. Nevame, R. M. Emon, and M. A. Malek, "Relationship between high temperature and formation of chalkiness and their effects on quality of rice," BioMed Research International, vol. 2018, Article ID 1653721, 18 pages, 2018. 
[32] S. Reyniers, N. De Brier, N. Ooms et al., "Amylose molecular fine structure dictates water-oil dynamics during deep-frying and the caloric density of potato crisps," Nature Food, vol. 1, no. 11, pp. 736-745, 2020.

[33] M. C. Bourne, Food Texture and Viscosity: Concept and Measurement, Elsevier Science \& Technology Books, Amsterdam, Netherlands, 2002.

[34] P. Mazumder, B. S. Roopa, and S. Bhattacharya, "Textural attributes of a model snack food at different moisture contents," Journal of Food Engineering, vol. 79, no. 2, pp. 511-516, 2007.

[35] A. M. Ziaiifar, F. Courtois, and G. Trystram, "Porosity development and its effect on oil uptake during frying process," Journal of Food Process Engineering, vol. 33, no. 2, pp. 191-212, 2010. 